\title{
The Using of ICT to Achieve Objectives Learning in Craft Education and Entrepreneurship
}

\author{
Amir Fatah ${ }^{1}$, Dinn Wahyudin ${ }^{2}$, Rusman $^{3}$ \\ \{amir.fatah3@gmail.com., dinn-wahyudin@ upi.edu.,rusman821971@gmail.com.\} \\ Universitas Pendidikan Indonesia
}

\begin{abstract}
The learning objectives of Craft and Entrepreneurship Education subjects are to facilitate students to develop themselves with education for life and at the same time to develop an independent life. To achieve this learning goal is certainly a difficult task because the entrepreneurial spirit is not easy to form and facilitating is learning activities that are not easy for teachers to do. The use of ICTs opens opportunities to achieve craft goals and entrepreneurial learning. It allows students to access, expand, change and share ideas and information of multi-modal communication. It helps students to share learning and space resources, promotes the principles of student-centered and collaborative learning and enhances critical thinking, creative thinking and problem solving skills. This study aims to find out how the use of ICT as a media and learning resources in craft and entrepreneurship conducted by teachers to achieve learning goals based on students' perceptions.
\end{abstract}

Keywords: ICT, Learning, Craft, Entrepreneurship.

\section{Introduction}

Entrepreneurship has long been understood as a key element in the growth process[1]. History records that in entrepreneurship education began in the early 1970s, at which time several universities in the world had provided the program[2]. Since then, interest in entrepreneurial education has continued to grow and most universities in the world have implemented it. In the US, entrepreneurship education has increased from 16 in 1970 to 504 in 2001[3], while the number of entrepreneurship programs at the undergraduate level is 1400 . The scope of entrepreneurship education has also expanded, not only to business schools but also in all fields of education at the university[4]Error! Reference source not found..

Along with the development of the number of schools that conduct entrepreneurship education, some experts still doubt about the impact of education. Several studies reveal the positive impact of entrepreneurial education[5], while others do not show impact [6] or even have a negative impact [7]Error! Reference source not found.. The results of research in the Middle East and North Africa show that entrepreneurship education has a positive impact on learners but is very small, namely between $1-4 \%$, while $46-87 \%$ are more likely to be yourself[1]. Whereas, as [1] also stated, the main purpose of entrepreneurship education is to build abilities, knowledge, and character formation that are important for entrepreneurial activity. 
The development of the entrepreneurship key competence is not simply a question of knowledge acquisition. Entrepreneurship education is about developing the ability to act in an entrepreneurial manner, attitude and behaviours are perhaps more important than knowledge about how to operation a business. Ref [8]Error! Reference source not found. that entrepreneurship education is not just developing entrepreneurial knowledge but also changing culture, where the competency is best obtained through research and mentoring. The role of the leader is important because it allows students to turn ideas into actions. Entrepreneurship education will not achieve learning objectives if it is only carried out through teacher-centered learning. This is because teacher-centered learning tends to be dominated by educators, while students only passively accept. Entrepreneurship education needs to be carried out with a different model, namely active learning, student-centered and providing training with the real world.

Development of entrepreneurship competencies in the younger generation, there needs to be a change in the role of the teacher [8]. The implementation of entrepreneurship education requires a significant change in the core aspects of learning, namely how teachers teach, how the role of the teacher changes from knowledge communicators to learning facilitators. Although this change is not easy to implement, the role of the teacher as a facilitator needs to be initiated and implemented so that the goals of entrepreneurial education can run optimally. This makes the teacher's role more complex, because entrepreneurship education not only teaches competence but also changes culture. [9] The teacher will certainly have difficulty identifying how to deal with inherent challenges. But on the other hand this shows that attention to the success of entrepreneurship education is very high. Therefore the teacher must play a central role in realizing these expectations.

In Indonesia, entrepreneurship education is combined with craft aimed at developing creative abilities, because entrepreneurship will not run without creating value-selling products[10]. Craft education and entrepreneurship within the 2013 curriculum framework are placed as compulsory lessons that emphasize aspects of the use of science and technology and local cultural wisdom. The implementation of these two aspects can be carried out in the form of crafting, engineering, cultivation and processing activities[11].

However, craft and entrepreneurship education in Indonesia has not fully provided a positive impact on the decline in the number of unemployed. Ref [12] February 2017 the number of open unemployment is 7.02 million people, which is dominated by high school graduates by 1.55 million. While the opportunity in 2017 there are 48.9 million Small and Medium Enterprises (SMEs) which absorb around $80 \%$ of the workforce and contribute $62 \%$ to GDP (excluding oil and gas). These data provide an overview of how much entrepreneurial activity (as reflected in the number of SMEs) in Indonesia. But this huge potential has not been used optimally, there are still many problems of unemployment and the poor and the income of the Indonesian people below the poverty line.

Entrepreneurship education must be able to form entrepreneurs by increasing knowledge about business and forming psychological attributes such as self-confidence, self-esteem and self-efficacy[13]. Education to give birth to entrepreneurship is a difficult task, not only because the entrepreneurial spirit is not easy to form, but mentoring learning activities that are not easily done by teachers[14]Error! Reference source not found.. The results of the study found that the average entrepreneur teacher was more functioned as a teacher who only conveyed knowledge rather than formed the soul of his students.

The use of ICTs opens opportunities to achieve the goals of Crafts Learning and Entrepreneurship. This is because it allows students to access, expand, change and share ideas and information in the style and format of multi-modal communication. It helps students to share learning and space resources, promotes the principles of student-centered and collaborative learning and enhances critical thinking, creative thinking and problem solving skills. 
This study seeks to provide an overview of the use of ICT in achieving the goals of learning Crafts and Entrepreneurship in secondary schools based on student perceptions.

\section{Theoretical}

\subsection{The objectives of Craft Education and Entrepreneurship}

Entrepreneurship education includes various audiences, goals, content and pedagogical methods[5]. The goal of entrepreneurship education most often cited by is to gain close knowledge of entrepreneurship, to acquire skills in the use of techniques, in analyzing business situations and in the synthesis of action plans, to identify and stimulate entrepreneurial drivers, talents and skills, to cancel the risk-bad bias from many analytical techniques, to develop empathy and support for unique aspects of entrepreneurship, to revise attitudes towards change, to encourage new start-ups and other entrepreneurial ventures, to stimulate affective elements of socialization[15]. The objectives of entrepreneurial education can be classified into three categories: raising awareness, teaching techniques, tools and how to handle situations and support project bearersError! Reference source not found.. Generally, entrepreneurial education aims to increase entrepreneurial awareness as a career choice and increase understanding of the processes involved in starting and managing new business enterprises.

The most important main and short-term results are to increase awareness, knowledge, and understanding of company concepts and practices / entrepreneurship, to develop individual skills / attitudes, attitudes and attitudes, to develop self-confidence and personal abilities, to develop empathy in a way of life entrepreneurship, to instill entrepreneurial values and beliefs, to motivate and inspire students towards a career or active life or entrepreneurship, to understand the business creation process, to develop generic entrepreneurial competencies, to develop the main business 'how to', to develop personal relationships and network skills, to prepare themselves to be freelancers or entrepreneurs, to start new businesses, and to exploit institutionally owned IPs [15]Error! Reference source not found.. On the other hand, entrepreneurship education results in long-term outcomes including changes in attitudes, culture, support systems and influences on businesses created by youth.

In Indonesia, the goals of craft and entrepreneurship education consist of two parts [16] namely material objectives and formal goals. Material objectives are to find, make work (products) of crafts, redesign products and develop products in the form of: crafts, engineering, cultivation and processing through activities of identifying, solving problems, designing, making, utilizing, evaluating, and developing products that are useful in daily life -day. While the skills developed are: the ability to modify, compose, develop, and create and reconstruct existing work, both own work and the work of others.

While the formal goals of craft education and entrepreneurship are developing creativity through: creating, designing, modifying (composing), and reconstructing based on basic technology education, entrepreneurship and local wisdom; train students' sense sensitivity to the development of science, technology and art to become innovators by developing: curiosity, a sense of caring, a sense of belonging, a sense of beauty and tolerance; build an independent and innovative spirit of students with character: honest, responsible, disciplined, and caring. Developing technological and aesthetic thinking: fast, precise, fixed and aesthetic, economical and practical and forging the courage to take risks in developing skills and implementing their knowledge.

\subsection{Information and Communication Technology in Learning}


The development of science and technology has brought significant changes to various dimensions of human life both in the economic, socio-cultural and educational fields. Since the beginning, education has always been open to new discoveries in technology. The problem of education and teaching is a complex problem where many factors influence it, one of these factors is the teacher. In education reform, teachers are the last but most important chain in the process of educational change. But when considering innovations related to ICT in education, the teacher can be considered as an obstacle[17]Error! Reference source not found.. This is because there are still many teachers who only carry out teaching routines without the desire to innovate, especially with regard to technology.

The teacher in carrying out the task of conveying the subject matter to students through the process of communication interaction in the teaching and learning process that does need to innovate. The success of the teacher in delivering the material is very dependent on the smooth interaction of communication between the teacher and students, the media is needed as an intermediary, in addition to the media in the teaching and learning process also requires the existence of learning technology, learning technology will determine the success of the learning process in achieving learning goals. This is in accordance with the main mission of Learning Technology, namely helping, triggering and spurring, the learning process, and providing facilities or learning facilities [18]Error! Reference source not found.. The achievement of learning objectives in the form of changes in knowledge, skills, and relatively fixed attitudes caused by experience, not because maturity is the main criterion of learning success.

The role of information technology in human activities at this time is indeed so great, technological development has influenced the world of education, especially in the learning process. Effective learning activities require a media that supports the absorption of as much information as possible[19]Error! Reference source not found.. Along with the times, technology plays an important role as a means to get the learning material taught. Technology and learning media are one of the supports that play an important role in improving the quality of human resources in the learning process. The presence of media in learning can help increase student understanding, the presentation of information is more interesting and trusted, facilitates data interpretation, and compresses information[8]Error! Reference source not found.. So in this case it is said that the function of media technology is as a means of assisting in the process of transferring knowledge or information in learning.

Information and Communication Technology (ICT) has three main functions used in learning activities[20], namely: Technology functions as a tool, in this case ICT is used as a tool for users (users) or students to help learning, for example in processing words, processing numbers, creating graphic elements, creating databases, making programs administrative for students, teachers and staff, staffing data, finance and so on. Technology also functions as science. In this case technology is part of a discipline that must be mastered by students. Finally, technology functions as a material and a tool for learning (literacy). In this case technology is interpreted as learning material as well as a tool to master computer-aided competence. In this case the computer has been programmed in such a way that students are guided in stages by using the principle of complete learning to master competence. In this case the position of technology is like a teacher who functions as: facilitator, motivator, transmitter, and evaluator. 


\section{Method and Data Collecting}

The subjects in this study were craft teachers and entrepreneurship who had more than five years of teaching experience and had been certified as professional teachers, as well as class X students who attended craft and entrepreneurship lessons. The object of the research was the learning process of Crafts and Entrepreneurship which was held in Public Middle Schools throughout Kulon Progo Regency which was selected as the research sample (purposive sampling). The criteria used are schools that have implemented the 2013 curriculum and represent urban, rural, mountainous and coastal areas.

The research data was collected using a questionnaire developed by researchers based on the standard of the process of learning implementation totaling 9 items using a 4-level Likert scale and supported by in-depth interviews with several representative students of each class. The construct validity test is done by asking the experts in the field of learning and measurement. While empirical validity is done by testing instruments. The results of testing the instrument with the number of respondents $n=30$ found the validity of the item statement ranged from 0.439 to 0.724 and alpha reliability coefficient of 0.96 . Data analysis to provide an overview of the use of ICT in achieving learning objectives used descriptive analysis.

\section{Results And Discussion}

Based on the data that is worth analyzing, it can be shown in Table 1 as follows:

Table 1. ICT as a Learning Source

\begin{tabular}{lll}
\hline No. & Statement & Score $(1-4)$ \\
\hline 1 & $\begin{array}{l}\text { Suitability of learning technology used by teachers } \\
\text { with learning needs }\end{array}$ & 2.52 \\
2 & $\begin{array}{l}\text { Suitability of learning resources chosen by the } \\
\text { teacher with the competencies to be achieved } \\
\text { The ease students get the learning resources } \\
\text { recommended by the teacher }\end{array}$ & 2.25 \\
& $\begin{array}{l}\text { The diversity of learning resources } \\
\text { recommended by the teacher }\end{array}$ & 2.54 \\
\hline
\end{tabular}

Based on Table 1. it can be seen that the use of ICT as a learning resource is still low. However, Suitability of learning technology used by teachers with learning needs has reached a high category as well as the diversity of learning resources recommended by the teacher.

Suitability of learning technology is used by teachers with learning needs so students rate $16.9 \%$ as very low; $37.0 \%$ low; $23.3 \%$ high and $22.8 \%$ very high. Likewise the Suitability of learning resources chosen by the teacher with the competencies to be achieved, students rated $18.5 \%$ felt very low; $43.4 \%$ low; $32.3 \%$ high and only $5.8 \%$ very high. The ease of students getting the learning resources recommended by the teacher, students rated $49.7 \%$ felt very low; $34.9 \%$ low; $11.1 \%$ high and $4.2 \%$ very high. The diversity of learning resources recommended by the teacher, students rated $16.4 \%$ felt very low; $29.6 \%$ low; $37.0 \%$ high and $16.9 \%$ very high. 
Table 2. ICT as a Learning Media

\begin{tabular}{llc}
\hline No. & Statement & Score (1-4) \\
\hline 1 & $\begin{array}{l}\text { Suitability of learning media chosen by the teacher } \\
\text { with the time available }\end{array}$ & 3.11 \\
2 & $\begin{array}{l}\text { Ease of obtaining learning media used by teachers } \\
\text { The ability of teachers to involve students in the use of } \\
3\end{array}$ & $\begin{array}{l}\text { learning media } \\
\text { Suitability of learning media chosen by the teacher } \\
\text { with learning objectives } \\
\text { The ability of teachers to use various media in } \\
\text { delivering learning messages }\end{array}$ \\
\hline
\end{tabular}

Based on Table 2. it can be seen that the use of ICT as a learning medium is still low. However Suitability of learning media is chosen by the teacher with the time available, the ability of teachers to involve students in the use of learning media, and Suitability of learning media chosen by the teacher with learning objectives.

Suitability of learning media is chosen by the teacher with the time available so students rate very low $6.9 \% ; 13.2 \%$ low; $34.9 \%$ high and $45.0 \%$ very high. Likewise, Ease of obtaining learning media is used by teachers, students score very low $48.7 \% ; 37.0 \%$ low; $13.2 \%$ high and only $1.1 \%$ very high. The ability of teachers to involve students in the use of learning media, students rated $7.4 \%$ felt very low; $20.1 \%$ low; $51.3 \%$ high and $21.1 \%$ very high. Suitability of learning media was chosen by the teacher with learning objectives students rated $10.6 \%$ felt very low; $36.0 \%$ low; $38.1 \%$ high and $15.3 \%$ very high. The ability of teachers to use various media in delivering learning messages is very low at $25.9 \% ; 47.6 \%$ low; $21.2 \%$ high and $5.3 \%$ very high

The low use of ICT in craft learning and entrepreneurship certainly affects the achievement of learning objectives. However, based on interviews conducted with 18 student representatives from the class who became the subject of the study showed that the learning objectives can be achieved well. This is because students try to find their own learning resources by browsing on the internet or youtube. More in-depth interviews found information that on average students always access the internet at school after school hours. They volunteered to go home late to get learning resources so they would not miss the learning material and be able to achieve the set competencies.

The results of interviews with teachers found that the experience of teachers in utilizing information technology was very limited. This is due to the lack of training followed and the age limitations that make motivation to improve competencies in the ICT field relatively low.

\section{Conclusion}

The results showed that the use of ICT to achieve the learning goals of craft and entrepreneurship was still in the low category. The ability of teachers to use ICT as learning resources and media needs to be improved. This is because in Indonesia, every year high school graduates are millions of students who cannot study at university. On average they will wait a long time to get a job. Crafting and entrepreneurial education are expected to achieve the goal of equipping high school graduates with an entrepreneurial spirit. The low use of ICT in learning needs to be the concern of teachers, principals, education offices and related 
institutions. Because ICT users can optimally enable them to achieve craft and entrepreneurial learning goals.

\section{References}

[1] P. Premand, S. Brodmann, and R. Almeida, "Entrepreneurship Education and Entry into SelfEmployment Among University Graduates," World Dev., Vol. 77, pp. 311-327 (2016).

[2] H. Landstrom, "Entrepreneurship research: A history of scholarly migration Historical d evelopment of entrepreneurship as a research field," No. August (2017).

[3] H. Vesper and B. Gartner, "Executive Forum Measuring Progress Education In," Vol. 26 (1997).

[4] D. Kuratko, "Entrepreneurship Education: Emerging Trends And Challenges For The $21 \mathrm{St}$ Century,"(2003).

[5] A. Fayolle, B. Gailly, and A. Fayolle, "From craft to science Teaching models and learning processes in entrepreneurship education," (2008).

[6] H. Haase and A. Lautenschla, "Students ' entrepreneurial intentions: an inter-regional comparison," No. 2008 (2009).

[7] H. Oosterbeek, M. V. P. Ã, and A. Ijsselstein, "The impact of entrepreneurship education on entrepreneurship skills,” Vol. 54, pp. 442-454 (2010).

[8] E. Report, Entrepreneurship Education in Europe at School. .

[9] S. . Gautan, M.K., Singh, "Entrepreneurship Education: Concept , Characteristics and Implications for Entrepreneurship Education : Concept, Characteristics," No. August, (2017).

[10] W. Christina, H. Purwoko, and A. Kusumowidagdo, "The Role of Entrepreneur in Residence towards the Students, Entrepreneurial Performance: A Study of Entrepreneurship Learning Process at Ciputra University, Indonesia," Vol. 211, No. September, pp. 972-976 (2015).

[11] C. Hadi, I. Suardi, and A. Cahaya, "Entrepreneurship and Education: Creating Business Awareness for Students in East Java Indonesia," Procedia - Soc. Behav. Sci., Vol. 177, No. July 2014, pp. 459-463 (2015).

[12] Biro Pusat Statistik, "Statistik Agustus 2017," No. 103, pp. 1-12 (2017).

[13] G. Packham, P. Jones, C. Miller, D. Pickernell, and B. Thomas, "Attitudes towards entrepreneurship education : a comparative analysis," No. September (2010).

[14] A. Winarno, "Entrepreneurship Education in Vocational Schools : Characteristics of Teachers , Schools and Risk Implementation of the Curriculum 2013 in Indonesia," vol. 7, no. 9, pp. 122 127 (2016).

[15] F. G. Alberti, S. Sciascia, and A. Poli, "Entrepreneurship Education: Notes on an Ongoing Debate Entrepreneurship Education : Notes on an Ongoing Debate,"No. January (2004).

[16] P. D. Hannon, "Teaching pigeons to dance : sense and meaning in entrepreneurship education," No. Cmi, (2003).

[17] W. N. Hidayat, M. A. Mizar, P. K. Universitas, and N. Malang, "Studi Integrasi Tik Dalam Pembelajaran Di Sekolah Menengah Kejuruan,” pp. 2281-2291 (2016).

[18] W. Pelgrum, "Discussion Paper Teachers, teacher policies and ICT," No. December, pp. 5-6 (2002).

[19] K. W.F, "Discussion Paper ICT and Educational Resource Policy," No. December, pp. 5-6 (2002).

[20] M. Chodzirin, "Pemanfaatan Information and Communication Technology bagi Pengembangan Guru Madrasah Sub Urban,” Vol. 16, No. November, pp. 309-332, (2016). 